NBER WORKING PAPER SERIES

\title{
PHYSICIAN BIAS AND RACIAL DISPARITIES IN HEALTH: EVIDENCE FROM VETERANS' PENSIONS
}

\author{
Shari Eli \\ Trevon D. Logan \\ Boriana Miloucheva \\ Working Paper 25846 \\ http://www.nber.org/papers/w25846
NATIONAL BUREAU OF ECONOMIC RESEARCH 1050 Massachusetts Avenue
Cambridge, MA 02138
May 2019

We thank Marcella Alsan, Rodney Andrews, Hoyt Bleakley, Dora Costa, Barry Eichengreen, Stanley Engerman, Michael Haines, Alexandre Mas, John Parman, Richard Steckel, Melissa Thomasson and Sven Wilson for their comments and suggestions. We thank seminar participants at the University of British Columbia, Colgate University, and the University of Maryland. We also thank participants of conference presentations of the American Economic Association, Canadian Network of Economic Historians, Population Association of America, and Social Science History Association. We thank Joseph Burton, Alex Orsini, Kory Potzler, Carlos Villareal, Andrea Zemp, Chris Roudiez, and Noelle Yetter at the Early Indicators Project for their advice and assistance with the United States Colored Troops sample. We gratefully acknowledge the financial support of the Social Sciences and Humanities Research Council of Canada as well as the Connaught Fund at the University of Toronto. William Biscarri and Kathleen Chen provided excellent research assistance. The project described was supported by Award Number P01 AG10120 from the National Institute on Aging. The content is solely the responsibility of the author(s) and does not necessarily represent the official views of the National Institute on Aging or the National Institute of Health. The views expressed herein are those of the authors and do not necessarily reflect the views of the National Bureau of Economic Research.

NBER working papers are circulated for discussion and comment purposes. They have not been peer-reviewed or been subject to the review by the NBER Board of Directors that accompanies official NBER publications.

(C) 2019 by Shari Eli, Trevon D. Logan, and Boriana Miloucheva. All rights reserved. Short sections of text, not to exceed two paragraphs, may be quoted without explicit permission provided that full credit, including (C) notice, is given to the source. 
Physician Bias and Racial Disparities in Health: Evidence from Veterans' Pensions

Shari Eli, Trevon D. Logan, and Boriana Miloucheva

NBER Working Paper No. 25846

May 2019

JEL No. I14,I3,N11

\begin{abstract}
We estimate racial differences in longevity using records from cohorts of Union Army veterans. Since veterans received pensions based on proof of disability at medical exams, estimates of the causal effect of income on mortality may be biased, as sicker veterans received larger pensions. To circumvent endogeneity bias, we propose an exogenous source of variation in pension income: the judgment of the doctors who certified disability. We find that doctors appeared to discriminate against black veterans. The discrimination we observe is acute-we would not observe any racial mortality differences had physicians not been racially biased in determining pension awards. The effect of income on health was indeed large enough to close the black-white mortality gap in the period. Our work emphasizes that the large effects of physicians' attitudes on racial differentials in health, which persist today amongst both veterans and the civilian population, were equally prominent in the past.
\end{abstract}

Shari Eli

Department of Economics

University of Toronto

150 St. George Street

Toronto, ON M5S 3G7

CANADA

and NBER

shari.eli@utoronto.ca

Trevon D. Logan

The Ohio State University

410 Arps Hall

1945 N. High Street

Columbus, OH 43210

and NBER

logan.155@osu.edu
Boriana Miloucheva

Department of Economics

University of Toronto

150 St. George Street

Toronto, ON M5S 3G7

Canada

boriana.miloucheva@mail.utoronto.ca 


\section{Introduction}

The recent literature on health disparities has started to focus on the relationship between white physicians and their African American patients. This includes analyses of mistrust in the black community toward public health officials and other medical practitioners, and racial bias in physician practice and perceptions of African American patients. For example, Alsan and Wanamaker (2017) showed that the disclosure of the Tuskegee Study of Untreated Syphilis in the Negro Male in 1972 led to high levels of mistrust of physicians amongst older black men, accounting for 35\% of the life expectancy gap between black and white men in $1980 .{ }^{1}$ Besides attitudes of mistrust stemming from black patients to their doctors, recent evidence has emerged that shows blacks are prescribed fewer pain medications than whites and offered fewer treatments, both surgical and otherwise, relative to their white counterparts (Hoffman (2003), Goyal et al. (2015)). Even more, recent evidence has shown that physicians exhibit significant bias in assessing the pain and treatment of their black patients (Hoffman et al., 2016), suggesting that physician bias can play a role in health outcomes.

In this paper, we focus on black health in the late nineteenth and very early twentieth century - a period in which health status was largely unaffected by public health interventions or medical treatment. ${ }^{2}$ Fogel (2004) and McKeown (1976) have emphasized the role of increases in standards of living, and in particular improvements in nutrition, as having most affected mortality prior to the introduction of modern medical techniques and drugs such as antibiotics. Indeed, recent analysis has stressed differences in disease environments, in which African Americans had baseline disease rates which were only seen among whites in epidemics (Humphreys, 2008; Downs, 2012). Therefore, studying the role of income on the origins of the black-white mortality gap is unlikely to be confounded by factors such as public health efforts. Scholarly work using veterans' records from the late 19 th and early 20 th century, has shown that increases in income led white veterans to retire earlier, improve the quality of their living arrangements and make other behavioral changes so as to increase longevity and reduce morbidity (see Costa (1995), Costa (1997), Eli (2015) and

\footnotetext{
${ }^{1}$ Comparable results have also been found in other contexts. Lowes and Montero (2018), for example, find that forced immunization campaigns by French Colonialists reduced trust in medical institutions.

${ }^{2}$ Our study period begins in 1897 and ends in 1906. For those living in cities after 1910, public health interventions such as water purification and the construction of sewer systems reduced mortality by as much as $50 \%$. See Cutler and Miller (2005) and Ferrie and Troesken (2005) who have contributed to this literature.
} 
Balan-Cohen (2007)).

We investigate the effect of income on the racial mortality gap by using evidence from pensions received by white and black veterans who served as Union Army soldiers during the American Civil War. The benefit of using the cohort of Union Army veterans is that we have information on pension income, health status and cause of death. ${ }^{3}$ Information on the health status of veterans is available since veterans were required to undergo medical exams by qualified surgeons and furnish the Pension Bureau with surgeons' reports in order to qualify for pensions.

Identification of the causal effect of income on mortality is complicated, however. Since veterans received pensions based on proof of disability at medical exams, estimates of the effect of pension income on mortality will be biased. Therefore, it will seem as though increases in pension income lead to a higher risk of mortality. To circumvent this endogeneity bias, we propose an exogenous source of variation in pension income: the idiosyncratic judgments of examining surgeons. While veterans were required to undergo examination, they had little choice in who performed their examinations. We provide the first known links of veterans to Pension Bureau physicians, who were called examining surgeons, by collecting and digitizing new records that contain the entire history of physician turnover within each board of surgeons. Thus, we are able to identify the physicians responsible for each examination and associate them directly with the outcome of the examination.

The medical literature at the time advanced the position that "black bodies" were inferior to white ones, which led some physicians to believe that the health of black veterans would not benefit from increased pension income. ${ }^{4}$ More generally, white physicians could have been less convinced of the veracity of the symptoms that black veterans reported. We argue that doctor bias in disability description is related to pension income but unrelated to the true underlying health of the pension recipient. Said differently, if a white and black veteran both suffered from the same condition, the black veteran often received a lower rating than the white veteran by the examining physician and

\footnotetext{
${ }^{3}$ This information was kept by the Pension Bureau, which was a sub-division of the federal government's Department of the Interior. These records were digitized by the Early Indicators Project at the University of Chicago. The Early Indicators Project is now part of the NBER. For more information, see uadata.org.

${ }^{4}$ See Hoffman (1896) for examples of scientific racism prevalent in the medical community in the period.
} 
thus received a lowered pension award. ${ }^{5}$ We expand this by exploring the impact of doctor bias on mortality for black and white veterans.

We show that the examining surgeons' views, as expressed in text on surgeons' certificates, influenced the pension ruling amount, and this is exogenous to the true health condition of the veteran. ${ }^{6}$ We find that an additional dollar in monthly pension income, which is equivalent to a 10 percent increase, led to an additional 0.3 years of life for all veterans. In addition, we find that the disparity in pension income that resulted from doctor bias explains nearly all of the gap in health outcomes between the races. Once we control for physician bias there is no residual racial disparity in mortality.

We extend these results and show that physician bias was more prevalent for medical conditions which were difficult to diagnose (such as digestive disorders) and therefore more sensitive to physician judgment, as opposed to those that could be verified with available technology. We also show that while doctors were much more likely to comment on the personality traits of black veterans as opposed to white veterans, there were no racial differences in veteran reports of pain or aches. Ultimately, we find that health disparities at this time were strongly related to racial bias by physicians.

The results of our work are relevant to discrimination in medicine today in several important ways. First, much of the literature on racial disparities in health focuses on access to care and less on the role of physicians in rating and treating subjective conditions such as pain or other discomforts. Second, physicians are still required to certify illness and disability for veterans seeking pension awards from the Veterans Administration (VA), and the VA still uses a similar rating system as its predecessor - the Union Army Pension Bureau. Third, our work uses a novel historical dataset in which we have information on health conditions spanning an individual's entire life as well as age at death. Thus, we can observe and measure the profound negative consequences that physician bias had on race differentials in health and longevity, since our follow-up periods are considerably longer than those of studies on individuals in the modern era. This allows us to see the durable

\footnotetext{
${ }^{5}$ Wilson (2010) provides a discussion of this pattern of discrimination by doctors.

${ }^{6}$ For the literature on the use of judges, physicians and other types of adjudicators as instruments, see Abrams et al. (2012) and Kostøl and Mogstad (2015)
} 
effects of physician bias on racial health disparities.

\section{Historical Background}

\subsection{The War Experience of U.S. Colored Troops}

The United States Colored Troops were comprised of 186,017 black soldiers, approximately 88,000 of whom enlisted in Confederate states. ${ }^{7}$ Another 46,000, enlisted in Border states, and of the remaining 46,000, some were likely born into slavery though free by the time of enlistment. ${ }^{8}$ Of the 33,000 black soldiers who died during the war, 4,000 died from wounds and the remainder succumbed to disease. ${ }^{9}$ The white battle mortality rate was significantly higher than that for blacks ${ }^{10}$ owing to the fact that blacks were purposely kept out of battle whenever possible. Whites were sent into battle more frequently than blacks because of common beliefs in the period that blacks were less "courageous" than whites in combat. Accordingly, troops in black regiments were assigned garrison duty during the war. A second reason why blacks were less likely to see battle than whites was due to the fact that blacks were believed to have greater immunity to pernicious diseases of the South, such as yellow fever and malaria, than northern white troops of the Union Army and therefore better used in field posts. ${ }^{11}$

While black soldiers were in part recruited for their perceived immunity to disease, they in fact suffered from higher rates of diarrhea, dysentery, pneumonia, tuberculosis, smallpox, and malaria. Therefore, the black mortality rate during the war was higher despite the fact that whites saw significantly more battle. Furthermore, even though blacks suffered higher rates of morbidity and mortality from disease during the war, they had greater difficulty gaining admission to army hospitals than their white counterparts during the conflict (Humphreys, 2013). Even when blacks were able to get care in hospitals, the condition of black hospital wards was hardly therapeutic. Black wards were often unsanitary and lacking in food, clean bedding, clothing and medicine for

\footnotetext{
${ }^{7}$ Humphreys (2008), p. 5.

${ }^{8}$ (ibid.)

${ }^{9}$ Humphreys (2008), p. 5-6.

${ }^{10}$ As many as 90,000 (4.5\%) of white soldiers died in battle in comparison with $1.8 \%$ of blacks. (Humphreys (2008), p. 10).

${ }^{11}$ Humphreys (2008), p. 45.
} 
their patients. ${ }^{12}$

\subsection{Race Differentials in Pension Receipt}

While pension legislation did not differ for white and black veterans, blacks faced difficulty in securing pensions. Between 1861 and 1934, the application success rate for white veterans was $92.6 \%$ while the rate for blacks was $75.4 \% .^{13}$ Furthermore, conditional on receiving a pension during the period between 1879 and 1900, the white/black ratio in pension awards climbed from 1.106 to $1.273 .{ }^{14}$ The reasons for the black-white differentials stem from racial discrimination during and after the war.

Many black veterans, especially ex-slaves, had difficulty proving that they had served in the Union Army because their post-war names did not match the name given to clerks at enlistment. There were three reasons for name changes: 1) Upon enlisting, slaves often submitted their masters' last names, which were changed after emancipation; 2) Likely to be illiterate, slaves were unable to correct enlistment clerks when their names were misspelled; 3) Many slaves escaped and enlisted under false names to prevent their enslavers from finding and reclaiming them. ${ }^{15}$ Uncertain of a black applicant's identity, pension clerks requested affidavits from members of the applicant's community to prove war service. However affidavits from other community members were often considered unreliable in the case files of black veterans, ${ }^{16}$ and unless black veterans sought information from their former enslavers, pensions were subsequently denied.

Prior to 1890, veterans could claim a pension under the General Law of 1862 if they faced illnesses or disabilities attributable to the war experience. In order to prove disability, all veterans were first required to send their applications to the Pension Bureau and to state their illness or injury. Upon receipt of the application, the Bureau assigned each veteran to an examining surgeon ${ }^{17}$ in his local area who certified that the veteran did, in fact, suffer from the disabilities stated on his

\footnotetext{
${ }^{12}$ Humphreys (2008), p. 79.

${ }^{13}$ Shaffer (2004), p. 209.

${ }^{14}$ Wilson (2010).

${ }^{15}$ Shaffer (2004), p. 124.

${ }^{16}$ Shaffer (2004), p. 129.

${ }^{17}$ After 1884 , the veteran was likely required to see a board of examining surgeons as the Pension Bureau no longer hired single surgeons to perform exams.
} 
application. The examining surgeon then completed a surgeons' certificate outlining the disabilities and their relationship to the veteran's war experience.

The surgeons' certificate was then sent directly from the surgeon's office to the Pension Bureau in Washington, D.C. Once the certificate was received at the Bureau, it was compared to the medical records from the war. If a veteran claimed a war-related disability, such as malaria or a gun shot wound, but there was no record of his admission to a war hospital for the illness or injury, he was likely to be denied a pension. Therefore, because black veterans had difficulty gaining access to hospitals during the war, they were unable to secure pensions in as large numbers compared to white veterans after the war.

After the passage of the Invalid Pensions Act of 1890, both white and black veterans could claim pensions for disabilities they faced that were unrelated to the war experience. Even then, the most common reason for pension denial (or lowered pensions relative to whites) was the inability of black veterans to prove their disabilities. Disabilities deserving of pensions included those which were verifiable during an exam, such as hernias, and those which were diagnosed on the basis of symptoms stated by the veteran, such as chronic diarrhea. ${ }^{18}$ Symptom lists from white veterans were more likely to be trusted by examining surgeons, while lists from black veterans were largely considered suspect. Testimony from black veterans was considered to be "reliable" by examining surgeons if the veteran displayed appropriate behavior typical of middle-class whites. ${ }^{19}$ The lack of cultural competence, discrimination, and disbelief led surgeons to assign lower disability ratings to blacks as compared to whites. Since surgeons' certificates for black veterans frequently had lower disability ratings, the medical examiners at the Pension Bureau were more likely to award lower pensions to black veterans. Indeed, as Figure 1 demonstrates, average payouts to black and white veterans saw a divergence after the 1890 law change, where previously the average payouts appear to follow each other quite closely.

After the passage of the Act of 1907, the Pension Bureau began awarding pensions to veterans based on their age, rather than on disability. Under the new act, veterans over the age of 62 were

\footnotetext{
${ }^{18}$ Wilson (2010) shows that the black/white approval ratio for pensions in which veterans claimed a hernia was 0.896 whereas the rate was 0.404 for diarrhea. For other unverifiable conditions, such as back pain and hearing loss, the black-white approval rates were 0.397 and 0.216 respectively.

${ }^{19}$ Shaffer (2004), p. 130.
} 
eligible to receive $\$ 12$ per month, and those over age 65 were eligible for higher amounts. However, even with the passage of the new act, black veterans continued to face difficulty when applying for pensions because many did not know their date of birth. ${ }^{20}$ The Acts of 1912 and 1918 increased the age based pensions further. While racial discrimination in the Union Army pension prevented many black veterans from receiving payments, current estimates show that the Pension Bureau dispersed a total of $\$ 313$ million to black veterans. ${ }^{21}$ In contrast, the system distributed over $\$ 125$ million annually to white veterans in the twentieth century.

\section{Data}

\subsection{Union Army Data}

We use the Union Army Dataset and the United States Colored Troops (USCT) sample compiled by the Early Indicators Project. ${ }^{22}$ Information in the dataset comes from three sources: the military, pension and medical records; surgeons' certificates; and census records. The military, pension and medical records contain socioeconomic and demographic data. These records are of particular importance because they contain information regarding the recruit's town and state of enlistment as well as his place of birth, which taken together are used to determine the slave status of the recruit. ${ }^{23}$ The surgeons' certificates provide individual-level descriptions composed by examining surgeons of a veteran's health status at the time of each exam.

Unlike the white Union Army veterans, it is unclear whether black veterans were representative of the average black male in the U.S. after the war. The sample of veterans contained in the Union Army sample is representative of the sample of white men found in the 1900 Census. For example, the mortality rate of white veterans in 1900 are similar to those of white men in the 1900 Census. $^{24}$ Of the soldiers who fought for the Union Army, the UA Data group collected records for 6,187

\footnotetext{
${ }^{20}$ Shaffer (2004), p. $129-130$.

${ }^{21}$ Ibid, p. 133.

${ }^{22}$ Union Army sample (NIA P01 AG10120, PI: Fogel), and Expanded United States Colored Troops (USCT) sample (NIA P01 AG10120, PI: Costa).

${ }^{23}$ Black veterans who enlisted in slave states are counted as having been slaves at enlistment in the dataset. Efforts by the UA data group to link black veterans, for whom a master's name was listed, to the Slaves Schedules were unsuccessful because of a lack of necessary personal identifiers to be certain that accurate linkages have been made.

${ }^{24}$ Costa (2008), p. $2-3$.
} 
veterans spanning 52 companies of the USCT. ${ }^{25}$

Despite being subject to the same laws, whites were able to secure higher pensions than blacks. In our sample, black veterans received an average monthly pension of $\$ 7.89$ while whites received \$11.01, and black veterans put in just as many pension applications as whites (see Table 1). Table 1 also contains summary statistics on age at death, state of residence and occupation for black veterans, who were on the pension rolls by 1897. Consistent with Figure 2, we find that white veterans live longer, but also appear to suffer more from disease conditions.

\subsection{Examining Surgeons dataset}

In order to determine the patterns of doctor subjectivity, it was necessary to collect the Pension Bureau's Rosters of Examining Surgeons found in the National Archives. We manually photographed and subsequently digitized the rosters for the years 1897 to 1907 which contain the following: 1) the town, county and state of exam sites; 2) the names of surgeons at each exam site; 3) the reason for the removal of examining surgeons from their post or the organization of boards is provided. ${ }^{26}$ On average, examining surgeons in our sample served for on average 1.86 years and performed 6 linked examinations.

Combining the information for all years, we then match the surgeon(s) to veterans for each exam by linking the surgeon(s) address from the rosters to the address found on each surgeons' certificate in the USCT dataset. It is not possible to match veterans to surgeons by linking the surgeons' names from the surgeons' certificate to names in the roster because the Union Army data does not contain the surgeons' names from the surgeons' certificates. For this reason, we create linkages using addresses. Additionally, because the Register of Examining Surgeons did not consistently contain information on the street address of the boards, matching an exam to a board

\footnotetext{
${ }^{25}$ In this analysis, we use only the subsample of veterans who were on the pension rolls by 1897 . This is because we only have information on boards of examining surgeons beginning in 1897 (see the section on Examining Surgeons for further explanation).

${ }^{26}$ The Register contains information on examining surgeons for the years 1862 to 1928 with the exception of the years 1887 to 1892 inclusive. Since we are only using exams that took place after the liberalization of the pension program by the Law of 1890 , we only digitized roster images after 1892 . Despite best efforts, the images for the rosters between the years 1892 to 1896 remain illegible. A sample of the register is provided in Figure 3 . As was common during the late nineteenth century, civil servants, including examining surgeons, were given their posts by newly elected or re-elected politicians as rewards for party loyalty.
} 
in large cities where multiple boards served is not possible. Importantly for our analysis, veterans were not necessarily assigned to the surgeon within their town and thus the geography of surgeons' offices does not dictate our results.

Once an application was put forward for evaluation, veterans were assigned to a particular physician board by the pension bureau. These assignments were made by the Pension Bureau, which meant that veterans were unable to select a particular board of physicians. Combined with long wait times for a meeting with a board, the frequent turnovers of the physicians meant that any attempts or strategies to see "more generous" boards were typically fruitless (Eli, 2015). Indeed, among

\subsection{Controls}

Controls in this analysis include an indicator equal to 1 if the veteran was born in the South. ${ }^{27}$ Including a control for being born in the South is necessary because early-life disease environments, which differ particularly between free and slave states, can affect late-life disease specific mortality rates. We also control for the veteran's birth year, height at enlistment, the number of battle wounds, and whether the veteran was enlisted in the rank of private. Each of these variables captures information about the war experience of the veteran, and has an impact on pension income.

Details of disease conditions faced during life come from the surgeons' certificates. To control for health status at the exam, we construct indicator variables equal to 1 if a veteran had a particular illness, which was described on a surgeons' certificate. We group morbidity conditions during life into the following categories: respiratory, digestive, diarrhea, infectious, cardiovascular, endocrine, genitourinary. ${ }^{28}$ We further construct an index measure of morbidity conditions present at the

\footnotetext{
${ }^{27}$ For black veterans, this also acts as a proxy for slave status. A veteran is assumed to have been born a slave if his birth state was was a slave state in 1861. These states include Delaware, Maryland, Virginia, North Carolina, South Carolina, Georgia, Florida, Alabama, Tennessee, Kentucky, Missouri, Arkansas, Mississippi, Louisiana, Oklahoma territory, Texas, the New Mexico Territory, and the Utah Territory.

${ }^{28}$ Respiratory illness include abscess, adhesion, allergy, asthma, atelectasis, atrophy, anthracosis, bronchiectasis, bronchitis, bronchorrhea, cavity, edema, effusion, emphysema, fibrosis, hemoptysis,homorrha, pleuritis, pneumonia, pneumonitis, pneumothorax, tracheitis and tuberculosis. Diarrhea includes constipation and dysentery. Digestive illnesses include dyspepsia, dysphagia, enlarged liver, enlarged spleen, gastro-enteritis, malassimilation (malabsorption), nausea and ulcers. Infectious illnesses include chancroid, cholera, dengue, diphtheria, gonorrhea, hepatitis, influenza, malaria, meningitis, mumps, orchitis, parotiditis, pertussis, pneumonia, rheumatic, rhinitis, rickettsia,
} 
veterans' previous exam (lagged health index). In doing so, we are able to capture changes to the underlying health of the veteran that could also drive changes in pension receipt.

Underneath the illness descriptions on surgeons' certificates, examining surgeons were required to rate the severity of the disability. While the surgeons' rating was often uncorrelated with pension payments for white veterans, ${ }^{29}$ the opposite was true for black veterans. Medical reviewers at the Pension Bureau relied heavily on the descriptions and ratings of examining surgeons in the cases of black veterans. ${ }^{30}$ Finally, we include a set of regional identifiers to capture broad geographic differences in health outcomes. ${ }^{31}$

\section{Empirical Strategy}

Prior to 1907, the Pension Bureau awarded payments to veterans based on the degree of their disabilities, which causes pension income to be endogenous with respect to health outcomes. Without instrumenting for pension income, the effect of pension payments on mortality will be biased causing it to appear as though increases in pensions cause higher rates of mortality. ${ }^{32}$ The instrument we use is a measure of the subjectivity of the board of examining surgeons that the veteran sees. In particular, we use the average pension a board recommended for all other veterans they examined - the leave-out mean.

In order to use the leave-out mean recommended by the board of surgeons as an instrument

rubella, salmonella, scarlet fever, septicaemia, streptococcus, syphilis, tetanus, tuberculosis, typhomalaria, varicella, variola, venereal, and yellow fever. Cardiovascular illnesses include arteriosclerosis, cyanosis, dyspnea, enlarged heart, impaired circulation, murmur, cardiac edema, and palpitation. Endocrine illnesses include diabetes, goiter and enlarged spleen. Genito-urinary illnesses include cystitis, enlarged prostate, nephritis, urethral obstruction, and uremia.

${ }^{29}$ The most important predictors of pension payment for white veterans was the type of disability and the congressional district of the veteran. See Eli (2015) for further explanation.

${ }^{30}$ Shaffer (2004) presents compelling evidence that the medical reviewers at the Pension Bureau held black applications for pensions to a higher standard than those of whites. For example, Shaffer shows that blacks were twice as likely as whites to have their pension application sent to "special examiners" for re-investigation. (p. 129)

${ }^{31}$ Because state health initiatives were largely non-existent, we use broad regional categories which better capture environmental factors and health conditions, comprising of the North (CT, DE, NJ, NY, PA, RI, VT, MA, ME, WI, OH, MN, MI, IN, NE, IL, IA), South (AL, AR, FL, GA, KS, LA, MS, NC, TN, TX, VA, OK), West (CA, WA, CO) and Border Regions (WV, MD, KY, MO).

${ }^{32}$ We use the sample of Union Army veterans who collected pensions by 1897. We follow individuals in our sample until 1906, which was the last year before the passage of the age-based pension laws. After the passage of these laws, the Pension Bureau began dispersing pensions based on age, and thus the judgments of examining surgeons did not determine pension awards for the majority of veterans. Therefore, the proposed instrument is only valid between 1893 and 1906. For a detailed explanation on our sample years, please see the Data section. 
for pension income, we must satisfy the following exclusion restriction: Conditional on our other control variables, the leave-out mean cannot impact the mortality of a veteran through any other channel except through pensions. Several additional assumptions must be made to fully validate the instrument. First, the average pension amount to others from the same board must have a relevant impact on the pension income received by the individual veteran. This is validated statistically in the first stage. Second, the health status of black veterans must be independent with respect to the average generosity of the physicians. Because veterans did not receive any useful medical treatment from examining surgeons (Eli, 2015), this assumption holds. Finally, it cannot be the case that black veterans from locations in which examining surgeons have relatively low average pension awards are more likely to apply for pensions than those from areas with a high average pension award, or vice versa. In our data, more than $85 \%$ of the black veterans (and more than $85 \%$ of white veterans) do not change locations. Given the extent to which information about the generosity of a particular physician is difficult to come by, the high rate of turn-over of physicians serving on examining boards, the distance a veteran would have to travel to see a different physician (if that physician was more generous), and the evidence that veterans who were rejected were highly likely to submit a second application to the same board, this restriction is also valid.

A key for our empirical strategy is the fact that the doctors were, themselves, of varying underlying levels of bias with respect to pension amounts they recommended. To the extent that pension recommendations were largely determined by demonstrable disabilities, physicians had some discretion when disabilities were not easily verifiable. In this respect, the racial bias of physicians provides us with exogenous differences in the pension receipt of the veteran that would not be related to underlying health condition of any particular veteran.

\subsection{Econometric Framework}

We estimate the effect of an extra dollar of monthly pension income on the age at death for both black and white Union Army veterans. ${ }^{33}$ However since pensions were received based on proof of

\footnotetext{
${ }^{33}$ Wage rates for blacks in the U.S. do not exist prior to 1940 . However, the average monthly income for a farmer in the Midwest was $\$ 24$ in 1900. Therefore, an extra dollar of pension income was equivalent to $4 \%$ of monthly income. Pensions likely replaced a much higher percentage of monthly income for blacks than whites.
} 
disability during medical exams, the effect of pensions on the age at death will be biased, making it appear as though increases in pension generosity lead to an earlier age at death. To circumvent the bias of the OLS regression, we implement an instrumental variables estimation strategy, where we instrument for pension income received using a measure of idiosyncratic physician stringency.

To avoid biasing the instrument using the outcome for the veteran in question, we construct the leave-out mean pension amount in the following way: ${ }^{34}$

$$
\text { LeaveOutMean }_{i j}=\frac{\sum_{k \neq i} \text { PensionAwarded }_{k j}-\text { PensionAwarded }_{i j}}{\text { NumExams }_{j}-1}
$$

where intuitively, LeaveOutMean ${ }_{i j}$ measures the average pension rating recommendation of the board $j$ who examines veteran $i$, for all examinations, $k$, other than the examination for veteran $i$ himself. In this respect, conditional on the random assignment of veterans to physicians, the instrument will be correlated with veteran $i$ 's pension if there is systematic physician subjectivity in rating decisions.

In the first stage, we regress the pension amount received by veteran $i$ in year $t$ on the leave-out mean for physician $j$ in year $t$, an indicator for race, the leave-out mean interacted with race, and a set of controls for health status, age, battle wounds and application (original or renewal). ${ }^{35}$

In the second stage specification takes the following form:

$$
\text { DeathAge }_{i}=f\left(\theta_{0}+\theta_{1} \hat{\operatorname{Pen}_{i j}}+\theta_{2} B_{i}+\theta_{3} \operatorname{Pen}_{i j} * B_{i}+\theta_{4} X_{i}+\epsilon_{i j}\right)
$$

where DeathAge is the age at death, $\hat{P e n}$ is the fitted value of pension received for person $i$ after seeing physician board $j$, and $X$ is the set of controls discussed above. We weight observations according to an inverse-use measure, which accounts for the number of times a veteran is observed during our sample period. In this way, particularly sick or particularly persistent veterans do not drive our results.

\footnotetext{
${ }^{34}$ Similar instruments have been used, in differing contexts in Maestas et al. (2013) and Bhuller et al. (2016), among others.

${ }^{35}$ Two first stages were run. Controls include the leave-out mean, and the leave-out mean interacted with black veteran status as well as all other covariates listed above.
} 


\section{Results}

We first present the OLS estimates of the longevity in Table $2 .{ }^{36}$ Since veterans were required to show proof of disability or illness in order to receive a pension, we would expect the coefficient on pension receipt to be biased. Table 2 shows that the coefficient on race is negative and significant. On average, a white veteran lived more than a year longer than black veterans, and the results also show that pension receipt did not have a differential effect for black veterans. OLS estimates also show that medical conditions diagnosed were negatively related to longevity, with the largest effects for cardiovascular diseases and respiratory diseases.

\subsection{Instrumental Variable Estimates}

Tables 3 and 4 report the instrumental variable estimates for our main estimation sample. When examining the first stage results in Table 3, we find that being assigned to a more generous board is positively associated with an increased pension. A one dollar increase in the average pension assigned to others by the board is associated with an increase in pension amount that ranges from $\$ 0.13$ to $\$ 0.28$ depending on the specification. We note that this relationship changes when examining black veterans, who appear to suffer a pension penalty, although this is not always statistically significant.

We find that having additional wounds sustained in battle (capturing both war time experience and severity of illness) predict an increase in pension receipt. Similarly, lagged health index (capturing the number of disease conditions reported in the previous examination) is associated with an increased pension. Since the pension law was designed to increase pension as illness increased, we find that the illnesses we control for largely increase pension amounts, as expected. Two notable exceptions are genitourinary and digestive conditions, which we find predict a decrease in the pension amount received. One reason for this reduction, particularly with genitourinary conditions, is that diseases resulting from "vicious habits" were typically heavily penalized by physician boards.

\footnotetext{
${ }^{36}$ Assignment to treatment, by matching veterans to the unique board performing the exam, yields over 5,400 unique exams. We note that the largest predictors of assignment to treatment in our set up is geographic location of the board and year of examination. Once city fixed effects are added to a probit model measuring assignment to treatment, race no longer predicts whether a veteran is in our estimating sample.
} 
In part, this reflected the predominant medical opinions of the time which related such diseases to moral shortcomings. A veteran presenting with, for example syphilis (or other sexually transmitted illnesses) will also have the associated genitourinary symptoms. Thus, a veteran with suspected vicious habits may receive a surgeons' certificate where both infections and genitourinary conditions are reported. We note, however, that infectious diseases can also be attributed to a large number of war-time infections, and thus would lead to a noisy prediction of pension receipt.

Digestive illnesses could similarly reflect the downward bias of "vicious habits" (by capturing the effects of excessive alcohol consumption on the liver). However, this bias might also be exacerbated by the difficulty in verifying claims of digestive illnesses. Conditions such as dysphagia (swallowing difficulties) and dyspepsia (indigestion) were unverifiable and remain so in medicine today, and thus required physician discretion and subjectivity in their diagnosis. Perhaps surprisingly, these first stage estimates seem to suggest no observable discrimination against blacks in pension receipt, once we condition on disease conditions.

Table 4 presents our IV results, estimating the causal impact of additional pension income on longevity. Consistent with prior literature, we find that an additional dollar in monthly pension income led to an additional 0.18 to 0.42 years of life depending on the specification. This is quite a large effect given that the average monthly pension amount ranged from $\$ 8$ per month for a black veteran and $\$ 11$ per month for a white veteran. We find no evidence, however, of a differential benefit in mortality for blacks as a result of pension receipt. As we would expect, disease burden shortens average life span, with the notable exception of digestive illness. While this result is perhaps initially counterintuitive, it is likely driven by the subjectivity of the diagnosis procedure.

Finally, the type of application made appears to matter. Renewal applications, made to restore a veteran to the pension rolls after having been dropped, appear to have a large and negative effect on longevity. This perhaps reflects the health toll resulting from the period of time spent without pension income. Applicants making an initial application (to be placed on the pension rolls), on the other hand, seem to fair much better. Indeed, this indicator likely captures the underlying good health of veterans who were ineligible for the pension prior. These large differences, however, highlight the need to examine different application types in more detail, which we discuss further 
in Section 6.

\subsection{Subjectivity and Discretion}

To further investigate the mechanism of physician discretion, we restrict our samples to veterans who present with an illness in two broad categories: subjective and externally verifiable (or objective). We take the example of two classes of verifiable illnesses, cardiovascular and infectious, both of which could be tested for with the medical equipment available to examining physicians. A subjective illness, by example digestive illnesses, were (and still are today) less easily verifiable by a physician during the course of an examination. Being subjective, both the presence and the severity of the illness, as recorded by the physician, would be largely due to physician discretion. We then limit the sample to veterans examinations in which at least the given disease condition was identified. Tables 5 and 6 investigate our preferred specification by individual disease categories, some of which would be more likely to be prone to discriminatory bias.

These results demonstrate an interesting pattern related to the allowed discretion given the illness reported. Table 5 demonstrates a similar pattern of first stage results as in our main specification. Assignment to a more generous examining board is associated with a higher pension. Pension boards are less generous to black veterans. However, the penalty to black veterans appears to be significantly larger for more subjective illnesses, particularly digestive diseases. Indeed, the penalty to black veterans offsets almost half the benefit otherwise received by seeing a more generous board.

Table 6 presents our second stage estimates, again by disease category. We find a pattern consistent with our main empirical specification for verifiable conditions. Pension receipt improves longevity, but it does not appear to do so differentially once we account for the bias of the physician. Interestingly however, this pattern appears to change when we restrict our sample to examinations presenting with relatively subjective conditions. We notice that pension receipt associated with seeing a more generous board of surgeons does differentially improve black mortality. However, this effect is modest compared to the very substantial black penalty in this sample. Blacks presenting with at least one digestive condition live, on average, 10 years less than their white counterparts. 
The results of Table 5 and Table 6 show that variation in doctor discretion appears to play a role in the determination of disability and pension receipt.

To consider the issue of physician bias in more detail, we also analyze the text of the physician certificates. Table 7 looks at the type of vocabulary used by physicians in their comments on the certificate. We take the certificates and divide them into two periods where pension rules gave physicians differing latitude in determining disability and pension amounts. The first period is before 1890, where veterans had to prove their injuries or diseases were a direct result of wartime experience (and physicians had little discretion once a war-related illness was proven in military or other records). The second period, between 1890 and 1907, was one of liberation of pension criteria as long as there was a disability, but the disability and severity was directed related to the physician rating. One striking finding which becomes evident across these two time periods is the dramatically different rates at which comments were made. ${ }^{37}$ While more exams were for white veterans (because more whites served than blacks), black veterans were between 5 and 8 times more likely to receive receive general physician comments than their white counterparts. The unbalanced rate of commenting between the races likely means that, across every category, black veterans are more likely to be described using positive terms like honest, truthful, or candid in order to justify providing a pension to them. Even more, the rate of racial differentiation in commenting is highest in the years with the greatest amount of physician discretion, which are the years between 1890 and 1907. The racial differential in commenting rates, irrespective of the type of comment, is remarkable.

However, black veteran were also disproportionately more likely to be described in negative terms. Our results further suggest that these negative comments were much more likely during the period of our study, when physicians had more discretion. They are over 15 times more likely to be described as "ignorant," 6 times more likely to be described as "stupid," and over 100 times more likely to be described as "illiterate." These comments suggest a clear pattern of discrimination, particularly in light of the fact that none of the descriptive terms are in any way medically relevant, or relevant to the potential outcome of the pension assessment. All but one

\footnotetext{
${ }^{37}$ We focus specifically on the class of additional comments, not related to a particular disease category (otherwise labeled "extra comments").
} 
of these negative descriptors experience an increase in prevalence after the changing of laws in 1890, further emphasizing the role that physician discretion had, and its support of potentially discriminatory practices.

It could be the case that veterans themselves presented different conditions driven by the liberalization of pension policy. It could also be the case that these would differ by race if black veterans were sicker than white veterans, on average. ${ }^{38}$ We explore this possibility in Table 8 , where we analyze the text that notes what the veterans reported to the physicians during their examinations. We find a striking pattern of stability in the comments by veterans themselves. For example, there is no discernible difference in the rate at which black and white veterans reported diarrhea, hurt, suffering, or pain before and after pension liberalization. This is further evidence that physician inferences from veteran statements, and the degree to which they believed some veterans more than others, was responsible for the differences in ratings.

One final note about these comments is important. The explicit intent of the Pension law was to be color blind, with eligibility criteria for black and white veterans identical, as was eligibility for benefits. Nevertheless, we find numerous instances of mention of the race of the veteran in the certificates. Moreover, while race is never mentioned before the 1890 pension reform, it is mentioned specifically thereafter. There is no medical reason, nor any reason related to pension eligibility or medical diagnoses, which would render any comment on race necessary.

\section{Robustness Checks}

We perform several robustness checks of our main results. To ensure the results are indeed driven by the match between the veteran and physician board, we randomly assign cases to a board of surgeons and re-estimate our preferred specification. Table 9 presents the results of this robustness exercise. We note that the board generosity is no longer predictive of pension receipt (with an F-stat consistently below 1), and our second stage is equally uninformative. Put another way, it is unlikely that idiosyncratic or random board assignment would explain our results.

We next focus on the two most prevalent application types, comprising over $95 \%$ of the appli-

\footnotetext{
${ }^{38}$ See Downs (2012) for more on illness among African Americans immediately after the Civil War.
} 
cations in our sample, original and disability increase applications. Original applications are made by veterans who have yet to make their way on to the pension. This can happen for a number of reasons, chief among them being the good health of the veteran, or discrimination faced by the veteran which prevented him from otherwise being compensated for legitimate illness. Disabilityincrease applications, as the name would suggest, are made by veterans who find their disability or illness has deteriorated, or to take advantage of a change in the law. Table 10 presents first stage predictors of pension receipt by application type.

We find that black applicants who have yet to make it onto the pension by the time period of our analysis (original applications) do, indeed face overt racial discrimination by surgeon boards. Interestingly, the generosity or stringency of a board has no effect on pension amount for original applicants overall, perhaps due to the large variation in disease burden. Nevertheless, we find that board generosity does have an effect for black applicants, but this effect is dwarfed by racial bias. The gap that we observe in Figure 1 is therefore driven by lower pension amounts in the original applications of black veterans. This is consistent with work by Wilson (2010), who finds that blacks face overt discrimination to make it onto the pension rolls, but this affect disappears with time. The results also show that the first stage pattern of disability increase applications mirrors the overall results.

\section{Conclusion}

We investigate the effect of income on the black-white mortality gap at the end of the 19th and early 20th century. Since pension income depends on health status in our setting, pension income is endogenous with respect to mortality. The estimates from our initial regressions also call attention to the need for an exogenous source of variation in pension income. Therefore, we propose a new instrument: the subjectivity of boards of examining surgeons in their pension recommendations for the Bureau. Boards were more likely to favor whites and recommend more generous pensions for similar disability claims. Therefore, we argue that racial discrimination led to differing pension amounts, which led to lower rates of longevity for blacks. Indeed, we find that accounting for physician discrimination in disability ratings eliminates racial differences in the effect of income on 
longevity.

Still today, physician bias and discrimination costs the black population in access to care, disability payments, and years of life. For instance, one of the leading causes of disability amongst veterans and in the general population is Chronic Obstructive Pulmonary Disease (COPD), which includes emphysema, chronic bronchitis and non-reversible asthma. The machine used to assess breathlessness caused by COPD - the spirometer - requires physicians to "eye-ball" the race of the patient since lung capacity is still assumed to be different across races as was first described in an 1869 study. ${ }^{39}$ Because the spirometer calibrates a lower lung capacity for blacks as opposed to whites, blacks today are rated as less disabled than whites when applying for disability pensions even though they have the same diagnostic scores as whites. ${ }^{40}$

Another important example of race differences in medicine lies in differences in the prescription of pain medication for surgical patients. ${ }^{41}$ As one example, Case and Deaton (2017) note that opioids were more likely to be prescribed to whites than to blacks due to physician beliefs about addition in the black population. This could also be driven by physician bias in pain ratings as well, where studies have documented that physicians believe that blacks experience less pain when they also held racially biased beliefs about the black body (Hoffman et al., 2016). Therefore, even though many medical theories rooted in scientific racism, such as the belief that the "black body" is stronger or weaker, are no longer ascribed to by physicians, discrimination and bias still underlies the medical system and becomes pernicious when rating disability based on subjective symptoms. Our study finds that similar types of biases have been a long standing feature of American medicine, and may be a key driver in the persistence of racial health disparities over time. Since our work uses a novel historical dataset in which we can observe the health experience of a patient over his entire lifetime, our work emphasizes the deleterious effects of physician bias and the need for further research on racial discrimination in medicine in both the past and the present.

\footnotetext{
${ }^{39}$ See Gould (1869) on Union Army and United States Colored Troop soldiers for the U.S. Sanitary Commission.

${ }^{40}$ See Braun (2014) for further explanation.

${ }^{41}$ See Goyal et al. (2015).
} 


\section{References}

Abrams, D. S., M. Bertrand, and S. Mullainathan (2012). Do judges vary in their treatment of race? The Journal of Legal Studies 41(2), 347-383. 3

Alsan, M. and M. Wanamaker (2017). Tuskegee and the health of black men. The Quarterly Journal of Economics 133(1), 407-455. 1

Balan-Cohen, A. (2007). Healthy, wealthy, and wise? the impact of the old age assistance program on elderly mortality in the united states. 2

Bhuller, M., G. B. Dahl, K. V. Løken, and M. Mogstad (2016). Incarceration, recidivism and employment. Technical report, National Bureau of Economic Research. 12

Braun, L. (2014). Breathing race into the machine: The surprising career of the spirometer from plantation to genetics. U of Minnesota Press. 19

Case, A. and A. Deaton (2017). Mortality and morbidity in the 21st century. Brookings papers on economic activity 2017, 397. 19

Costa, D. L. (1995). Pensions and retirement: Evidence from union army veterans. The Quarterly Journal of Economics 110(2), 297-319. 1

Costa, D. L. (1997). Displacing the family: Union army pensions and elderly living arrangements. Journal of Political Economy 105(6), 1269-1292. 1

Cutler, D. and G. Miller (2005). The role of public health improvements in health advances: the twentieth-century united states. Demography 42(1), 1-22. 1

Downs, J. (2012). Sick from Freedom: African-American Illness and Suffering during the Civil War and Reconstruction. Oxford University Press. 1, 17

Eli, S. (2015). Income effects on health: Evidence from union army pensions. The Journal of Economic History 75(2), 448-478. 1, 9, 10, 11 
Ferrie, J. P. and W. Troesken (2005). Death and the city: Chicago's mortality transition, 1850-1925. Technical report, National Bureau of Economic Research. 1

Fogel, R. W. (2004). The escape from hunger and premature death, 1700-2100: Europe, America, and the Third World, Volume 38. Cambridge University Press. 1

Gould, B. A. (1869). Investigations in the military and anthropological statistics of American soldiers, Volume 2. US sanitary commission. 19

Goyal, M. K., N. Kuppermann, S. D. Cleary, S. J. Teach, and J. M. Chamberlain (2015). Racial disparities in pain management of children with appendicitis in emergency departments. JAMA pediatrics 169(11), 996-1002. 1, 19

Hoffman, B. (2003). Scientific racism, insurance, and opposition to the welfare state: Frederick 1. hoffman's transatlantic journey. The Journal of the Gilded Age and Progressive Era 2(2), 150-190. 1

Hoffman, F. L. (1896). Race traits and tendencies of the American Negro, Volume 11. American Economic Association. 2

Hoffman, K. M., S. Trawalter, J. R. Axt, and M. N. Oliver (2016). Racial bias in pain assessment and treatment recommendations, and false beliefs about biological differences between blacks and whites. Proceedings of the National Academy of Sciences 113(16), 4296-4301. 1, 19

Humphreys, M. (2008). Intensely human: The health of the black soldier in the American Civil War. JHU Press. 1, 4, 5

Humphreys, M. (2013). Marrow of tragedy: The health crisis of the American Civil War. JHU Press. 4

Kostøl, A. R. and M. Mogstad (2015). Earnings, disposable income, and consumption of allowed and rejected disability insurance applicants. American Economic Review 105(5), 137-41. 3

Lowes, S. R. and E. Montero (2018). The legacy of colonial medicine in central africa. 1 
Maestas, N., K. J. Mullen, and A. Strand (2013). Does disability insurance receipt discourage work? using examiner assignment to estimate causal effects of ssdi receipt. American Economic Review 103(5), 1797-1829. 12

McKeown, T. (1976). The modern rise of population. 1

Shaffer, D. R. (2004). After the glory: The struggles of black civil war veterans. University Press of Kansas Lawrence. 5, 6, 7, 10

Wilson, S. E. (2010). Prejudice \& policy racial discrimination in the union army disability pension system, 1865-1906. American journal of public health $100(\mathrm{~S} 1)$, S56-S65. 3, 5, 6, 18 


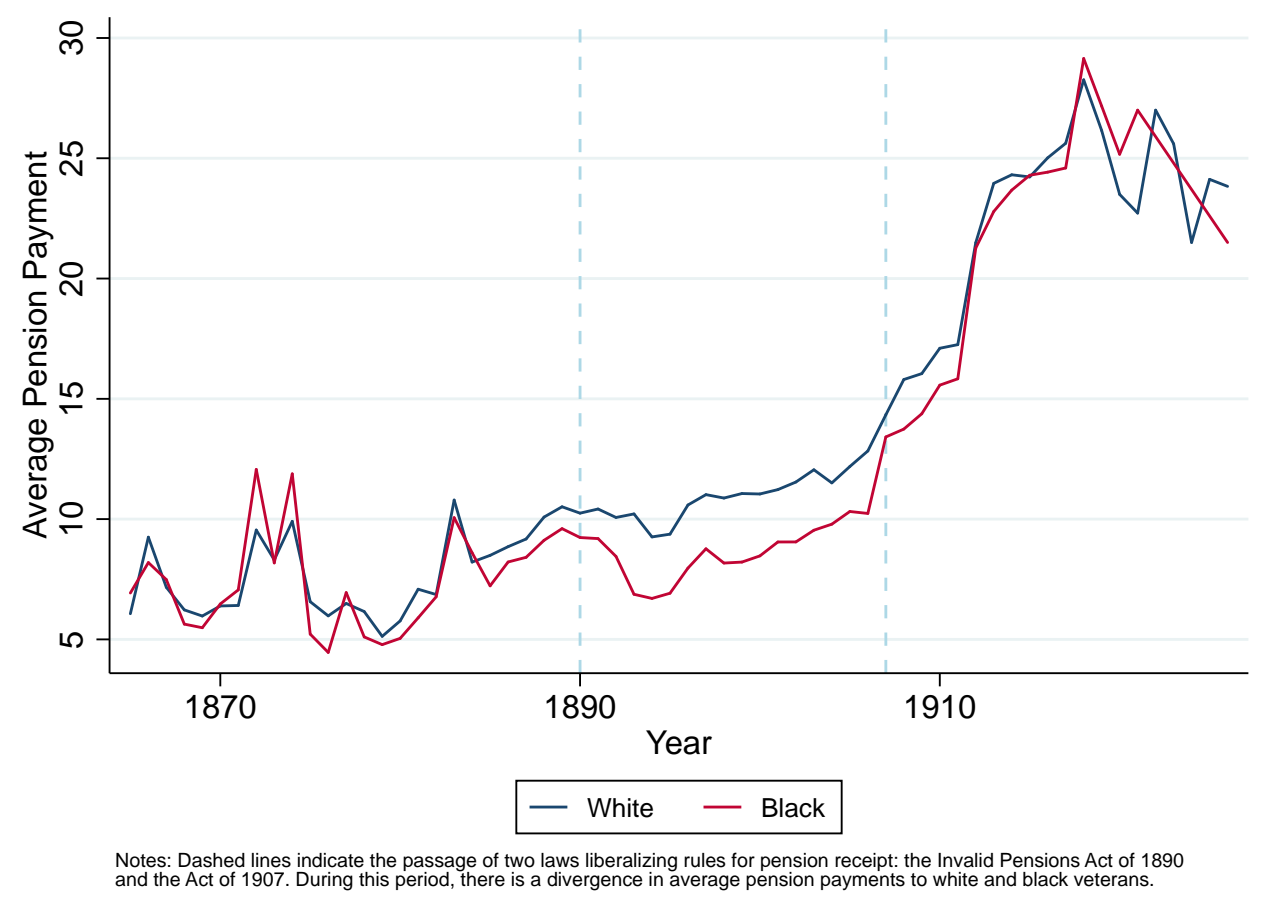

Figure 1: Average Monthly Pension Receipt

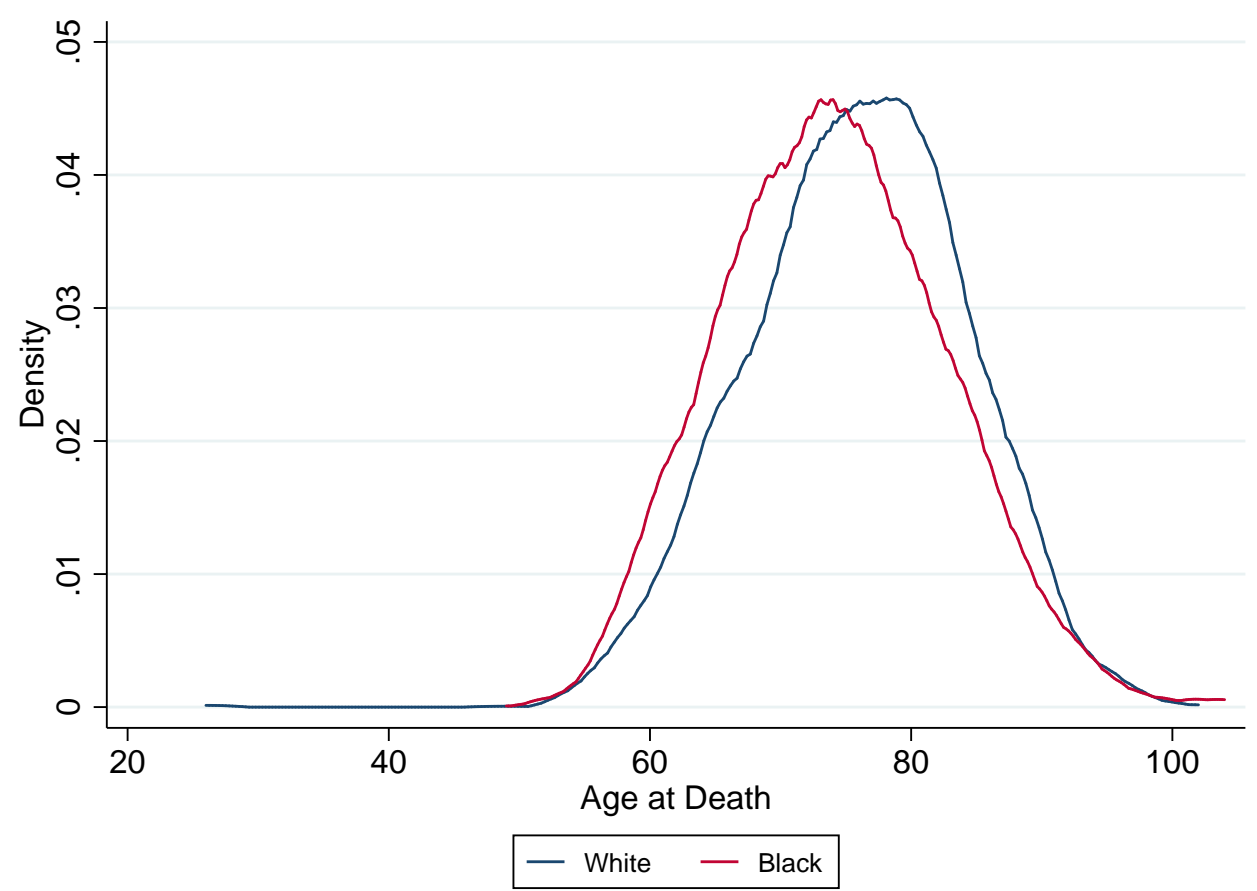

Figure 2: Age at Death 
Table 1: Summary Statistics for White and Black Union Army Veterans by 1897

\begin{tabular}{|c|c|c|}
\hline & White & Black \\
\hline Pension Received & 11.01 & 7.89 \\
\hline \multicolumn{3}{|l|}{ Enlistment Records } \\
\hline Average Birth Year & 1839.36 & 1840.16 \\
\hline Height & 67.8 & 66.7 \\
\hline Slave Status at Birth (\%) & $\mathrm{N} / \mathrm{A}$ & 76 \\
\hline \multicolumn{3}{|l|}{ War Experience } \\
\hline Initial Rank of Private (\%) & 91 & 94 \\
\hline Average no. of battle wounds & 0.5 & 0.2 \\
\hline \multicolumn{3}{|l|}{ Disease Conditions Ever Present (\%) \& Death } \\
\hline Cardiovascular & 53.8 & 48.0 \\
\hline Digestive & 23.9 & 13.8 \\
\hline Endocrine & 5.9 & 2.4 \\
\hline Genitourinary & 7.1 & 7.6 \\
\hline Infectious & 16.4 & 18.9 \\
\hline Diarrhea & 21.8 & 11.5 \\
\hline Average Age at Death & 75.9 & 74.1 \\
\hline No. of Veterans who apply or on rolls by 1897 & 2,567 & 1,438 \\
\hline No. of Exams & 3,629 & 2,510 \\
\hline
\end{tabular}




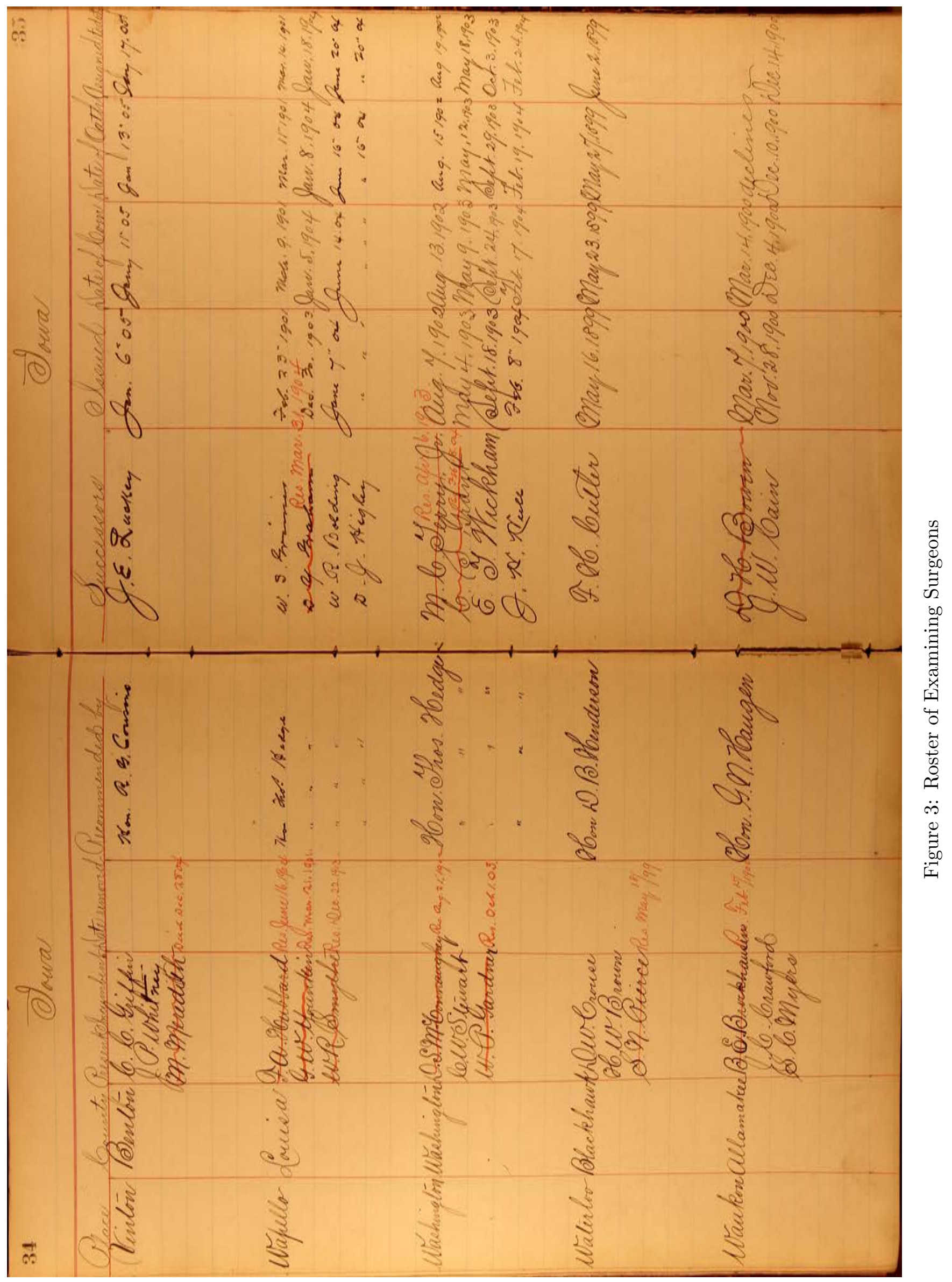


Table 2: OLS estimates of the effect of pension on age at death

\begin{tabular}{|c|c|c|c|c|}
\hline & $(1)$ & $(2)$ & $(3)$ & $(4)$ \\
\hline Pension Amount & $\begin{array}{l}-0.023 \\
(0.024)\end{array}$ & $\begin{array}{l}-0.029 \\
(0.026)\end{array}$ & $\begin{array}{c}-0.062^{* *} \\
(0.026)\end{array}$ & $\begin{array}{c}-0.061^{* *} \\
(0.026)\end{array}$ \\
\hline Pension Amount * Black & $\begin{array}{c}0.038 \\
(0.051)\end{array}$ & $\begin{array}{c}0.065 \\
(0.065)\end{array}$ & $\begin{array}{c}0.061 \\
(0.062)\end{array}$ & $\begin{array}{c}0.060 \\
(0.062)\end{array}$ \\
\hline Black & $\begin{array}{c}-2.154^{* * *} \\
(0.632)\end{array}$ & $\begin{array}{c}-2.431^{* * *} \\
(0.773)\end{array}$ & $\begin{array}{c}-2.189^{* * *} \\
(0.752)\end{array}$ & $\begin{array}{c}-2.170^{* * *} \\
(0.754)\end{array}$ \\
\hline Lagged Health Index & $\begin{array}{l}-0.033 \\
(0.044)\end{array}$ & $\begin{array}{l}-0.023 \\
(0.050)\end{array}$ & $\begin{array}{c}-0.076 \\
(0.049)\end{array}$ & $\begin{array}{c}-0.076 \\
(0.049)\end{array}$ \\
\hline Diarrhea & $\begin{array}{l}-0.011 \\
(0.321)\end{array}$ & $\begin{array}{c}0.292 \\
(0.365)\end{array}$ & $\begin{array}{c}0.413 \\
(0.362)\end{array}$ & $\begin{array}{c}0.410 \\
(0.363)\end{array}$ \\
\hline Respiratory & $\begin{array}{c}-0.944^{* * *} \\
(0.293)\end{array}$ & $\begin{array}{c}-0.685^{* *} \\
(0.345)\end{array}$ & $\begin{array}{c}-0.751^{* *} \\
(0.340)\end{array}$ & $\begin{array}{c}-0.765^{* *} \\
(0.340)\end{array}$ \\
\hline Infectious & $\begin{array}{c}-0.498^{*} \\
(0.285)\end{array}$ & $\begin{array}{c}-0.919^{* * *} \\
(0.329)\end{array}$ & $\begin{array}{c}-0.946^{* * *} \\
(0.327)\end{array}$ & $\begin{array}{c}-0.951^{* * *} \\
(0.327)\end{array}$ \\
\hline Cardiovascular & $\begin{array}{c}-1.030^{* * *} \\
(0.221)\end{array}$ & $\begin{array}{c}-1.123^{* * *} \\
(0.257)\end{array}$ & $\begin{array}{c}-1.176^{* * *} \\
(0.254)\end{array}$ & $\begin{array}{c}-1.171^{* * *} \\
(0.255)\end{array}$ \\
\hline Digestive & $\begin{array}{c}0.749^{* *} \\
(0.305)\end{array}$ & $\begin{array}{c}0.876^{* *} \\
(0.348)\end{array}$ & $\begin{array}{c}0.956^{* * *} \\
(0.345)\end{array}$ & $\begin{array}{c}0.958^{* * *} \\
(0.346)\end{array}$ \\
\hline Endocrine & $\begin{array}{l}-0.654 \\
(0.592)\end{array}$ & $\begin{array}{l}-0.501 \\
(0.647)\end{array}$ & $\begin{array}{c}0.017 \\
(0.644)\end{array}$ & $\begin{array}{c}0.021 \\
(0.645)\end{array}$ \\
\hline Genitourinary & $\begin{array}{c}0.693^{*} \\
(0.397)\end{array}$ & $\begin{array}{c}0.538 \\
(0.447)\end{array}$ & $\begin{array}{c}0.314 \\
(0.443)\end{array}$ & $\begin{array}{c}0.313 \\
(0.444)\end{array}$ \\
\hline Birth Year & $\begin{array}{c}-0.516^{* * *} \\
(0.020)\end{array}$ & $\begin{array}{c}-0.494^{* * *} \\
(0.022)\end{array}$ & $\begin{array}{c}-0.528^{* * *} \\
(0.022)\end{array}$ & $\begin{array}{c}-0.529 * * * \\
(0.022)\end{array}$ \\
\hline Height at Enlistment & $\begin{array}{r}-0.072^{*} \\
(0.042)\end{array}$ & $\begin{array}{r}-0.085^{*} \\
(0.049)\end{array}$ & $\begin{array}{c}-0.085^{*} \\
(0.048)\end{array}$ & $\begin{array}{c}-0.086^{*} \\
(0.048)\end{array}$ \\
\hline Wounds Sustained in battle & $\begin{array}{c}0.031 \\
(0.118)\end{array}$ & $\begin{array}{c}0.128 \\
(0.132)\end{array}$ & $\begin{array}{c}0.155 \\
(0.130)\end{array}$ & $\begin{array}{c}0.156 \\
(0.130)\end{array}$ \\
\hline Born in South & $\begin{array}{c}0.312 \\
(0.417)\end{array}$ & $\begin{array}{c}0.510 \\
(0.500)\end{array}$ & $\begin{array}{c}0.129 \\
(0.492)\end{array}$ & $\begin{array}{c}0.174 \\
(0.514)\end{array}$ \\
\hline Increase Application & $\begin{array}{c}0.985 \\
(0.649)\end{array}$ & $\begin{array}{c}0.445 \\
(0.684)\end{array}$ & $\begin{array}{c}0.162 \\
(0.675)\end{array}$ & $\begin{array}{c}0.204 \\
(0.678)\end{array}$ \\
\hline Initial Application & $\begin{array}{c}1.745^{* *} \\
(0.725)\end{array}$ & $\begin{array}{c}1.177 \\
(0.784)\end{array}$ & $\begin{array}{l}1.331^{*} \\
(0.776)\end{array}$ & $\begin{array}{l}1.361^{*} \\
(0.779)\end{array}$ \\
\hline Renewal Application & $\begin{array}{c}-4.265^{* * *} \\
(1.291)\end{array}$ & $\begin{array}{c}-5.259^{* * *} \\
(1.373)\end{array}$ & $\begin{array}{c}-4.309 * * * \\
(1.342)\end{array}$ & $\begin{array}{c}-4.314^{* * *} \\
(1.346)\end{array}$ \\
\hline Observations & 5,488 & 5,488 & 5,488 & 5,488 \\
\hline Weight & - & $\mathrm{X}$ & $\mathrm{X}$ & $\mathrm{X}$ \\
\hline Year FE & - & - & $\mathrm{X}$ & $\mathrm{X}$ \\
\hline Region FE & - & - & - & $\mathrm{X}$ \\
\hline
\end{tabular}


Table 3: IV First Stage Estimates of Main Estimating Sample

\begin{tabular}{|c|c|c|c|}
\hline & $(1)$ & $(2)$ & $(3)$ \\
\hline Leave-out Mean & $\begin{array}{c}0.283^{* * *} \\
(0.0388)\end{array}$ & $\begin{array}{c}0.243^{* * *} \\
(0.0469)\end{array}$ & $\begin{array}{c}0.233^{* * *} \\
(0.0476)\end{array}$ \\
\hline Leave-out Mean * Black & $\begin{array}{c}-0.0952^{* *} \\
(0.0476)\end{array}$ & $\begin{array}{c}-0.0717 \\
(0.0566)\end{array}$ & $\begin{array}{c}-0.0688 \\
(0.0568)\end{array}$ \\
\hline Black & $\begin{array}{l}-0.516 \\
(0.496)\end{array}$ & $\begin{array}{l}-0.632 \\
(0.615)\end{array}$ & $\begin{array}{l}-0.693 \\
(0.619)\end{array}$ \\
\hline Lagged Health Index & $\begin{array}{c}0.153 * * * \\
(0.0296)\end{array}$ & $\begin{array}{c}0.163 * * * \\
(0.0358)\end{array}$ & $\begin{array}{c}0.162^{* * *} \\
(0.0358)\end{array}$ \\
\hline Diarrhea & $\begin{array}{c}0.773^{* * *} \\
(0.200)\end{array}$ & $\begin{array}{c}0.813^{* * *} \\
(0.241)\end{array}$ & $\begin{array}{c}0.809^{* * *} \\
(0.241)\end{array}$ \\
\hline Respiratory & $\begin{array}{l}0.0411 \\
(0.184)\end{array}$ & $\begin{array}{c}0.00163 \\
(0.230)\end{array}$ & $\begin{array}{l}0.0217 \\
(0.231)\end{array}$ \\
\hline Infectious & $\begin{array}{c}-0.0480 \\
(0.180)\end{array}$ & $\begin{array}{l}0.0605 \\
(0.234)\end{array}$ & $\begin{array}{l}0.0647 \\
(0.234)\end{array}$ \\
\hline Cardiovascular & $\begin{array}{c}0.826^{* * *} \\
(0.128)\end{array}$ & $\begin{array}{c}0.795^{* * *} \\
(0.156)\end{array}$ & $\begin{array}{c}0.779 * * * \\
(0.156)\end{array}$ \\
\hline Digestive & $\begin{array}{c}-0.405^{* *} \\
(0.165)\end{array}$ & $\begin{array}{c}-0.439^{* *} \\
(0.200)\end{array}$ & $\begin{array}{c}-0.448^{* *} \\
(0.200)\end{array}$ \\
\hline Endocrine & $\begin{array}{c}0.781^{* *} \\
(0.382)\end{array}$ & $\begin{array}{c}0.817^{*} \\
(0.484)\end{array}$ & $\begin{array}{l}0.829^{*} \\
(0.486)\end{array}$ \\
\hline Genitourinary & $\begin{array}{c}-0.937 \text { *** } \\
(0.207)\end{array}$ & $\begin{array}{c}-0.890^{* * *} \\
(0.271)\end{array}$ & $\begin{array}{c}-0.886 * * * \\
(0.270)\end{array}$ \\
\hline Birth Year & $\begin{array}{c}-0.183^{* * *} \\
(0.0139)\end{array}$ & $\begin{array}{c}-0.182^{* * *} \\
(0.0169)\end{array}$ & $\begin{array}{c}-0.181^{* * *} \\
(0.0169)\end{array}$ \\
\hline Height at Enlistment & $\begin{array}{c}0.0583^{* *} \\
(0.0268)\end{array}$ & $\begin{array}{c}0.0608^{*} \\
(0.0345)\end{array}$ & $\begin{array}{l}0.0627^{*} \\
(0.0345)\end{array}$ \\
\hline Wounds Sustained in Battle & $\begin{array}{c}0.157^{*} \\
(0.0805)\end{array}$ & $\begin{array}{c}0.230^{* * *} \\
(0.0888)\end{array}$ & $\begin{array}{l}0.229 * * \\
(0.0890)\end{array}$ \\
\hline Born in South & $\begin{array}{l}-0.126 \\
(0.201)\end{array}$ & $\begin{array}{l}-0.155 \\
(0.253)\end{array}$ & $\begin{array}{l}-0.110 \\
(0.277)\end{array}$ \\
\hline Initial Rank is PVT & $\begin{array}{c}0.299 \\
(0.239)\end{array}$ & $\begin{array}{c}0.227 \\
(0.299)\end{array}$ & $\begin{array}{c}0.236 \\
(0.300)\end{array}$ \\
\hline Increase Application & $\begin{array}{c}1.297^{* * *} \\
(0.322)\end{array}$ & $\begin{array}{c}1.536^{* * *} \\
(0.359)\end{array}$ & $\begin{array}{c}1.505^{* * *} \\
(0.360)\end{array}$ \\
\hline Initial Application & $\begin{array}{c}-2.705^{* * * *} \\
(0.341)\end{array}$ & $\begin{array}{c}-2.584^{* * * *} \\
(0.385)\end{array}$ & $\begin{array}{c}-2.593^{* * *} \\
(0.388)\end{array}$ \\
\hline Renewal Application & $\begin{array}{l}-1.000 \\
(0.816)\end{array}$ & $\begin{array}{l}-0.808 \\
(1.112)\end{array}$ & $\begin{array}{l}-0.785 \\
(1.119)\end{array}$ \\
\hline Observations & 5,488 & 5,488 & 5,488 \\
\hline Weights & - & $\mathrm{X}$ & $\mathrm{X}$ \\
\hline Region FE & - & - & $\mathrm{X}$ \\
\hline F-stat & 39.66 & 20.73 & 17.93 \\
\hline
\end{tabular}


Table 4: IV Second Stage Estimates of Main Estimating Sample

\begin{tabular}{|c|c|c|c|}
\hline & (1) & $(2)$ & $(3)$ \\
\hline Pension Amount & $\begin{array}{c}0.311^{* *} \\
(0.137)\end{array}$ & $\begin{array}{c}0.366^{* *} \\
(0.185)\end{array}$ & $\begin{array}{c}0.421^{* *} \\
(0.201)\end{array}$ \\
\hline Pension Amount * Black & $\begin{array}{c}0.0605 \\
(0.165)\end{array}$ & $\begin{array}{c}0.0830 \\
(0.212)\end{array}$ & $\begin{array}{l}0.0898 \\
(0.220)\end{array}$ \\
\hline Black & $\begin{array}{l}-1.683 \\
(1.588)\end{array}$ & $\begin{array}{l}-1.717 \\
(2.085)\end{array}$ & $\begin{array}{l}-1.668 \\
(2.150)\end{array}$ \\
\hline Lagged Health Index & $\begin{array}{c}-0.137^{* * *} \\
(0.0508)\end{array}$ & $\begin{array}{l}-0.153^{* *} \\
(0.0612)\end{array}$ & $\begin{array}{c}-0.162^{* *} \\
(0.0630)\end{array}$ \\
\hline Diarrhea & $\begin{array}{l}-0.282 \\
(0.356)\end{array}$ & $\begin{array}{c}-0.0205 \\
(0.418)\end{array}$ & $\begin{array}{c}-0.0613 \\
(0.427)\end{array}$ \\
\hline Respiratory & $\begin{array}{c}-1.037^{* * *} \\
(0.302)\end{array}$ & $\begin{array}{c}-0.771^{* *} \\
(0.357)\end{array}$ & $\begin{array}{c}-0.802^{* *} \\
(0.362)\end{array}$ \\
\hline Infectious & $\begin{array}{c}-0.487^{*} \\
(0.293)\end{array}$ & $\begin{array}{c}-0.966^{* * *} \\
(0.343)\end{array}$ & $\begin{array}{c}-0.972^{* * *} \\
(0.346)\end{array}$ \\
\hline Cardiovascular & $\begin{array}{c}-1.407^{* * *} \\
(0.268)\end{array}$ & $\begin{array}{c}-1.564^{* * *} \\
(0.316)\end{array}$ & $\begin{array}{c}-1.589 * * * \\
(0.323)\end{array}$ \\
\hline Digestive & $\begin{array}{c}0.963^{* * *} \\
(0.313)\end{array}$ & $\begin{array}{c}1.131^{* * *} \\
(0.359)\end{array}$ & $\begin{array}{c}1.168^{* * *} \\
(0.364)\end{array}$ \\
\hline Endocrine & $\begin{array}{l}-0.600 \\
(0.624)\end{array}$ & $\begin{array}{l}-0.329 \\
(0.699)\end{array}$ & $\begin{array}{l}-0.388 \\
(0.713)\end{array}$ \\
\hline Genitourinary & $\begin{array}{c}0.871^{* *} \\
(0.424)\end{array}$ & $\begin{array}{c}0.694 \\
(0.485)\end{array}$ & $\begin{array}{c}0.739 \\
(0.495)\end{array}$ \\
\hline Birth Year & $\begin{array}{c}-0.475^{* * *} \\
(0.0339)\end{array}$ & $\begin{array}{c}-0.451^{* * *} \\
(0.0424)\end{array}$ & $\begin{array}{c}-0.442^{* * *} \\
(0.0448)\end{array}$ \\
\hline Height at Enlistment & $\begin{array}{c}-0.0911^{* *} \\
(0.0442)\end{array}$ & $\begin{array}{c}-0.112^{* *} \\
(0.0521)\end{array}$ & $\begin{array}{c}-0.117^{* *} \\
(0.0531)\end{array}$ \\
\hline Wounds Sustained in Battle & $\begin{array}{c}-0.0135 \\
(0.122)\end{array}$ & $\begin{array}{c}0.0617 \\
(0.142)\end{array}$ & $\begin{array}{l}0.0500 \\
(0.144)\end{array}$ \\
\hline Born in South & $\begin{array}{c}0.200 \\
(0.447)\end{array}$ & $\begin{array}{c}0.234 \\
(0.540)\end{array}$ & $\begin{array}{c}0.199 \\
(0.558)\end{array}$ \\
\hline Initial Eank is PVT & $\begin{array}{c}0.811^{*} \\
(0.451)\end{array}$ & $\begin{array}{c}0.498 \\
(0.504)\end{array}$ & $\begin{array}{c}0.474 \\
(0.509)\end{array}$ \\
\hline Increase Application & $\begin{array}{c}0.210 \\
(0.695)\end{array}$ & $\begin{array}{l}-0.580 \\
(0.774)\end{array}$ & $\begin{array}{l}-0.619 \\
(0.792)\end{array}$ \\
\hline Initial Application & $\begin{array}{c}2.915^{* * *} \\
(0.898)\end{array}$ & $\begin{array}{c}2.504^{* *} \\
(1.021)\end{array}$ & $\begin{array}{c}2.671^{* *} \\
(1.048)\end{array}$ \\
\hline Renewal Application & $\begin{array}{c}-3.220^{* *} \\
(1.313)\end{array}$ & $\begin{array}{c}-3.934^{* * *} \\
(1.353)\end{array}$ & $\begin{array}{c}-3.912^{* * *} \\
(1.374)\end{array}$ \\
\hline Observations & 5,488 & 5,488 & 5,488 \\
\hline Weights & - & $\mathrm{X}$ & $\mathrm{X}$ \\
\hline Region FE & - & - & $\mathrm{X}$ \\
\hline
\end{tabular}



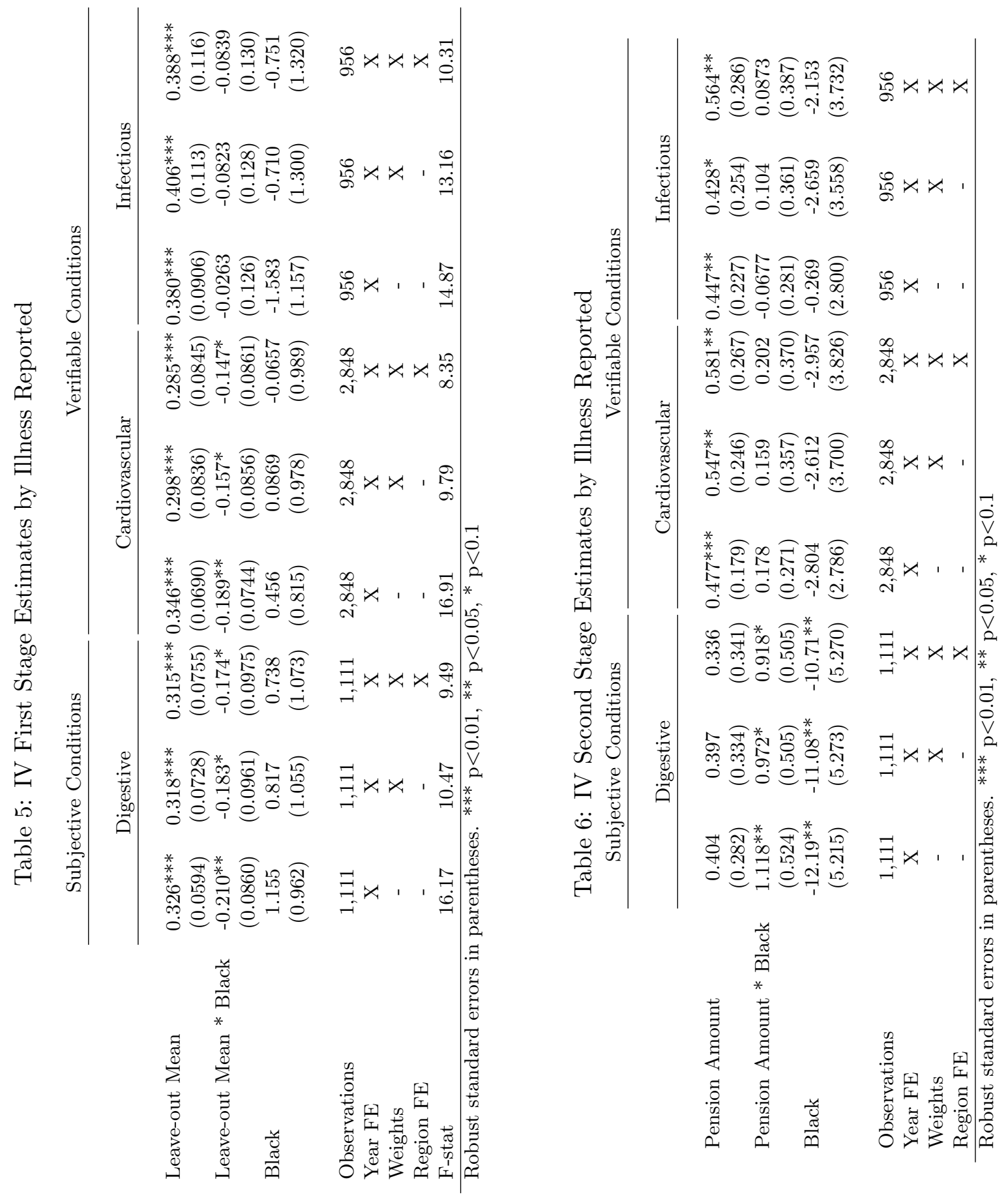
Table 7: Changing Patterns of Board Comments over Time

\begin{tabular}{|c|c|c|c|c|c|c|}
\hline & \multicolumn{3}{|c|}{ Pre - 1890} & \multicolumn{3}{|c|}{$1890-1907$} \\
\hline & Black & White & Ratio & Black & White & Ratio \\
\hline Any General Comments & 15.414 & 2.346 & 6.57 & 15.141 & 1.899 & 7.97 \\
\hline Honest & 0.178 & 0.013 & 13.89 & 0.120 & 0.013 & 9.20 \\
\hline Truthful & 0.059 & 0.008 & 7.72 & 0.023 & 0.002 & 12.27 \\
\hline Reliable & 0.040 & 0.010 & 3.86 & 0.006 & 0.002 & 3.07 \\
\hline Industrious & 0.059 & 0.008 & 7.72 & 0.029 & 0.004 & 7.67 \\
\hline Clever & 0.000 & 0.000 & - & 0.006 & 0.000 & - \\
\hline Benefit of the doubt & 0.000 & 0.000 & - & 0.000 & 0.004 & 0.00 \\
\hline Trustworthy & 0.000 & 0.000 & - & 0.011 & 0.000 & - \\
\hline Candid & 0.000 & 0.000 & - & 0.011 & 0.002 & 6.13 \\
\hline Ignorant & 0.079 & 0.000 & - & 0.057 & 0.004 & 15.34 \\
\hline Insane & 0.020 & 0.013 & 1.54 & 0.023 & 0.015 & 1.53 \\
\hline Stupid & 0.020 & 0.000 & - & 0.011 & 0.002 & 6.13 \\
\hline Illiterate & 0.277 & 0.010 & 27.01 & 2.610 & 0.022 & 116.81 \\
\hline Liar & 0.000 & 0.003 & 0.00 & 0.011 & 0.007 & 1.53 \\
\hline Exaggerate & 0.000 & 0.000 & - & 0.006 & 0.002 & 3.07 \\
\hline Doubt & 0.119 & 0.018 & 6.61 & 0.051 & 0.020 & 2.51 \\
\hline Vicious habits & 0.890 & 0.208 & 4.29 & 0.982 & 0.210 & 4.67 \\
\hline Colored & 0.317 & 0.000 & - & 0.451 & 0.000 & - \\
\hline Race & 0.000 & 0.000 & - & 0.034 & 0.000 & - \\
\hline Number of Exams & 5054 & 38997 & & 17509 & 53704 & \\
\hline
\end{tabular}

Table 8: Changing Patterns of Claimant Statements over Time

\begin{tabular}{|c|c|c|c|c|c|c|}
\hline \multirow{3}{*}{ Any General Comments } & \multicolumn{3}{|c|}{ Pre - 1890} & \multicolumn{3}{|c|}{$1890-1907$} \\
\hline & Black & White & Ratio & Black & White & Ratio \\
\hline & 97.962 & 77.137 & 1.270 & 97.984 & 97.872 & 1.001 \\
\hline Pain & 26.039 & 23.674 & 1.100 & 29.522 & 30.804 & 0.958 \\
\hline Suffering & 4.254 & 2.751 & 1.546 & 4.244 & 2.711 & 1.565 \\
\hline Aches & 1.088 & 0.862 & 1.263 & 1.148 & 1.181 & 0.972 \\
\hline Hurt & 0.772 & 0.595 & 1.297 & 1.788 & 1.356 & 1.319 \\
\hline Diarrhea & 7.163 & 14.865 & 0.482 & 9.429 & 21.393 & 0.441 \\
\hline Number of Exams & 5,054 & 38,997 & & 17,509 & 53,704 & \\
\hline
\end{tabular}


Table 9: Robustness Check: Random Assignment to Board

\begin{tabular}{|c|c|c|c|}
\hline & (1) & $(2)$ & (3) \\
\hline & \multicolumn{3}{|c|}{ First Stage } \\
\hline Leave-out Mean & $\begin{array}{l}-0.0142 \\
(0.0250)\end{array}$ & $\begin{array}{l}-0.0159 \\
(0.0287)\end{array}$ & $\begin{array}{l}-0.0157 \\
(0.0286)\end{array}$ \\
\hline Leave-out Mean * Black & $\begin{array}{c}0.00882 \\
(0.0314)\end{array}$ & $\begin{array}{c}0.0117 \\
(0.0369)\end{array}$ & $\begin{array}{c}0.00989 \\
(0.0367)\end{array}$ \\
\hline Black & $\begin{array}{c}-1.766^{* * *} \\
(0.375) \\
\end{array}$ & $\begin{array}{c}-1.657^{* * *} \\
(0.458)\end{array}$ & $\begin{array}{c}-1.690^{* * *} \\
(0.455)\end{array}$ \\
\hline \multirow[t]{2}{*}{ F-stat } & 0.20 & 0.17 & 0.18 \\
\hline & \multicolumn{3}{|c|}{ Second Stage } \\
\hline Pension Amount & $\begin{array}{l}-0.947 \\
(3.117)\end{array}$ & $\begin{array}{l}-0.759 \\
(2.975)\end{array}$ & $\begin{array}{l}-0.750 \\
(2.957)\end{array}$ \\
\hline Pension Amount $*$ Black & $\begin{array}{c}0.874 \\
(2.283)\end{array}$ & $\begin{array}{c}0.471 \\
(2.642)\end{array}$ & $\begin{array}{c}0.465 \\
(2.590)\end{array}$ \\
\hline Black & $\begin{array}{l}-11.26 \\
(22.39)\end{array}$ & $\begin{array}{l}-7.075 \\
(25.27)\end{array}$ & $\begin{array}{l}-7.033 \\
(24.89)\end{array}$ \\
\hline Observations & 5,488 & 5,488 & 5,488 \\
\hline Year FE & $\mathrm{X}$ & $\mathrm{X}$ & $\mathrm{X}$ \\
\hline Weights & - & $\mathrm{X}$ & $\mathrm{X}$ \\
\hline Region FE & - & - & $\mathrm{X}$ \\
\hline
\end{tabular}


Table 10: IV First Stage Estimates by Applicant Type

\begin{tabular}{|c|c|c|c|c|c|c|}
\hline \multirow[b]{2}{*}{ Leave-out Mean } & \multicolumn{3}{|c|}{ Original Applications } & \multicolumn{3}{|c|}{ Disability Increase Applications } \\
\hline & $\begin{array}{l}0.00907 \\
(0.0862)\end{array}$ & $\begin{array}{c}-0.0825 \\
(0.102)\end{array}$ & $\begin{array}{c}-0.155 \\
(0.0999)\end{array}$ & $\begin{array}{c}0.283^{* * *} \\
(0.0427)\end{array}$ & $\begin{array}{c}0.248^{* * * *} \\
(0.0518)\end{array}$ & $\begin{array}{c}0.242^{* * *} \\
(0.0526)\end{array}$ \\
\hline Leave-out Mean * Black & $\begin{array}{c}0.343^{* * *} \\
(0.102)\end{array}$ & $\begin{array}{c}0.411^{* * *} \\
(0.115)\end{array}$ & $\begin{array}{c}0.387^{* * *} \\
(0.112)\end{array}$ & $\begin{array}{c}-0.111^{* *} \\
(0.0534)\end{array}$ & $\begin{array}{c}-0.0917 \\
(0.0638)\end{array}$ & $\begin{array}{c}-0.0827 \\
(0.0644)\end{array}$ \\
\hline Black & $\begin{array}{c}-3.303^{* * *} \\
(1.001)\end{array}$ & $\begin{array}{c}-3.735^{* * *} \\
(1.153)\end{array}$ & $\begin{array}{c}-3.921^{* * *} \\
(1.145)\end{array}$ & $\begin{array}{c}-0.428 \\
(0.570)\end{array}$ & $\begin{array}{c}-0.512 \\
(0.710)\end{array}$ & $\begin{array}{c}-0.618 \\
(0.719)\end{array}$ \\
\hline Lagged Health Index & $\begin{array}{c}0.155^{*} \\
(0.0849)\end{array}$ & $\begin{array}{c}0.150 \\
(0.102)\end{array}$ & $\begin{array}{c}0.160 \\
(0.101)\end{array}$ & $\begin{array}{c}0.160^{* * *} \\
(0.0322)\end{array}$ & $\begin{array}{c}0.169^{* * *} \\
(0.0393)\end{array}$ & $\begin{array}{c}0.169^{* * *} \\
(0.0393)\end{array}$ \\
\hline Diarrhea & $\begin{array}{c}0.885 \\
(0.691)\end{array}$ & $\begin{array}{c}0.643 \\
(0.671)\end{array}$ & $\begin{array}{c}0.503 \\
(0.631)\end{array}$ & $\begin{array}{c}0.726^{* * *} \\
(0.214)\end{array}$ & $\begin{array}{c}0.813^{* * *} \\
(0.265)\end{array}$ & $\begin{array}{c}0.819^{* * *} \\
(0.265)\end{array}$ \\
\hline Respiratory & $\begin{array}{c}-0.0859 \\
(0.385)\end{array}$ & $\begin{array}{c}0.0891 \\
(0.471)\end{array}$ & $\begin{array}{c}0.223 \\
(0.446)\end{array}$ & $\begin{array}{l}0.0671 \\
(0.207)\end{array}$ & $\begin{array}{c}-0.00645 \\
(0.257)\end{array}$ & $\begin{array}{c}0.00743 \\
(0.257)\end{array}$ \\
\hline Infectious & $\begin{array}{c}-0.845^{* * *} \\
(0.309)\end{array}$ & $\begin{array}{c}-0.880^{* *} \\
(0.374)\end{array}$ & $\begin{array}{c}-0.851^{* *} \\
(0.363)\end{array}$ & $\begin{array}{c}0.138 \\
(0.213)\end{array}$ & $\begin{array}{c}0.245 \\
(0.275)\end{array}$ & $\begin{array}{c}0.249 \\
(0.276)\end{array}$ \\
\hline Cardiovascular & $\begin{array}{c}1.718^{* * *} \\
(0.259)\end{array}$ & $\begin{array}{c}1.510^{* * *} \\
(0.297)\end{array}$ & $\begin{array}{c}1.487^{* * *} \\
(0.293)\end{array}$ & $\begin{array}{c}0.704^{* * *} \\
(0.146)\end{array}$ & $\begin{array}{c}0.705^{* * *} \\
(0.179)\end{array}$ & $\begin{array}{c}0.694^{* * *} \\
(0.179)\end{array}$ \\
\hline Digestive & $\begin{array}{c}0.338 \\
(0.450)\end{array}$ & $\begin{array}{c}0.519 \\
(0.549)\end{array}$ & $\begin{array}{c}0.347 \\
(0.538)\end{array}$ & $\begin{array}{c}-0.449^{* *} \\
(0.182)\end{array}$ & $\begin{array}{c}-0.500^{* *} \\
(0.220)\end{array}$ & $\begin{array}{c}-0.501^{* *} \\
(0.220)\end{array}$ \\
\hline Endocrine & $\begin{array}{c}-0.0265 \\
(0.728)\end{array}$ & $\begin{array}{c}0.277 \\
(0.823)\end{array}$ & $\begin{array}{c}0.325 \\
(0.759)\end{array}$ & $\begin{array}{l}0.831^{*} \\
(0.426)\end{array}$ & $\begin{array}{c}0.831 \\
(0.540)\end{array}$ & $\begin{array}{c}0.822 \\
(0.543)\end{array}$ \\
\hline Genitourinary & $\begin{array}{c}-0.138 \\
(0.533)\end{array}$ & $\begin{array}{l}-0.332 \\
(0.643)\end{array}$ & $\begin{array}{r}-0.0551 \\
(0.642)\end{array}$ & $\begin{array}{c}-1.102^{* * *} \\
(0.231)\end{array}$ & $\begin{array}{c}-1.012^{* * *} \\
(0.307)\end{array}$ & $\begin{array}{c}-1.001^{* * *} \\
(0.307)\end{array}$ \\
\hline Birth Year & $\begin{array}{c}-0.149 * * * \\
(0.0336)\end{array}$ & $\begin{array}{c}-0.146^{* * *} \\
(0.0374)\end{array}$ & $\begin{array}{c}-0.141^{* * *} \\
(0.0366)\end{array}$ & $\begin{array}{c}-0.180 * * * \\
(0.0155)\end{array}$ & $\begin{array}{c}-0.179^{* * *} \\
(0.0191)\end{array}$ & $\begin{array}{c}-0.179 * * * \\
(0.0191)\end{array}$ \\
\hline Height at Enlistment & $\begin{array}{c}0.0772 \\
(0.0546)\end{array}$ & $\begin{array}{l}0.132^{* *} \\
(0.0588)\end{array}$ & $\begin{array}{c}0.154^{* * *} \\
(0.0581)\end{array}$ & $\begin{array}{c}0.0502 \\
(0.0306)\end{array}$ & $\begin{array}{c}0.0477 \\
(0.0394)\end{array}$ & $\begin{array}{c}0.0486 \\
(0.0395)\end{array}$ \\
\hline Wounds Sustained in Battle & $\begin{array}{l}-0.327 \\
(0.240)\end{array}$ & $\begin{array}{l}-0.456 \\
(0.279)\end{array}$ & $\begin{array}{c}-0.462^{*} \\
(0.270)\end{array}$ & $\begin{array}{c}0.189^{* *} \\
(0.0908)\end{array}$ & $\begin{array}{c}0.270^{* * *} \\
(0.0986)\end{array}$ & $\begin{array}{c}0.268^{* * *} \\
(0.0986)\end{array}$ \\
\hline Born in South & $\begin{array}{c}0.0784 \\
(0.430)\end{array}$ & $\begin{array}{l}-0.159 \\
(0.512)\end{array}$ & $\begin{array}{l}1.046^{*} \\
(0.593)\end{array}$ & $\begin{array}{l}-0.275 \\
(0.231)\end{array}$ & $\begin{array}{l}-0.284 \\
(0.289)\end{array}$ & $\begin{array}{l}-0.322 \\
(0.312)\end{array}$ \\
\hline Initial Rank is PVT & $\begin{array}{l}0.0741 \\
(0.497)\end{array}$ & $\begin{array}{l}0.0644 \\
(0.570)\end{array}$ & $\begin{array}{l}-0.115 \\
(0.556)\end{array}$ & $\begin{array}{c}0.296 \\
(0.274)\end{array}$ & $\begin{array}{c}0.221 \\
(0.342)\end{array}$ & $\begin{array}{c}0.235 \\
(0.343)\end{array}$ \\
\hline Observations & 772 & 772 & 772 & 4,511 & 4,511 & 4,511 \\
\hline Year FE & $\mathrm{X}$ & $\mathrm{X}$ & $\mathrm{X}$ & $\mathrm{X}$ & $\mathrm{X}$ & $\mathrm{X}$ \\
\hline Weights & - & $\mathrm{X}$ & $\mathrm{X}$ & - & $\mathrm{X}$ & $\mathrm{X}$ \\
\hline Region FE & - & - & $\mathrm{X}$ & - & - & $\mathrm{X}$ \\
\hline F-stat & 19.95 & 18.83 & 10.34 & 30.18 & 15.94 & 14.85 \\
\hline
\end{tabular}

